\title{
HISTORICAL USE OF NITROGEN AND PHOSPHORUS FERTILIZERS IN RAIN-FED REGIONS AND THEIR CONSEQUENTIAL IMPLICATIONS ON WATER QUALITY IN THE PACIFIC NORTHWEST, USA
}

\author{
R.L. MAHLER ${ }^{1} \&$ M.E. BARBER ${ }^{2}$ \\ ${ }^{1}$ Department of Soil and Water Systems, University of Idaho, Moscow, ID, USA \\ ${ }^{2}$ Department of Civil and Environmental Engineering, University of Utah, Salt Lake City, UT, USA
}

\begin{abstract}
Nitrogen $(\mathrm{N})$ and phosphorus $(\mathrm{P})$ fertilizers are major sources of surface water and/or groundwater pollution in the Pacific Northwest. Soil scientists have tried to increase the efficiency of these nutrients in crop production within the region by refining both the rates of application, timing of application and placement of these nutrients within soils. The purpose of this article is to document changes in the use of these nutrients since 1971. To do this four mail-based grower surveys were conducted in 1981, 1996, 2011 and 2016 to document changing $\mathrm{N}$ and $\mathrm{P}$ fertilizer use and their methods of placement within soils. In addition, the surveys documented erosion control efforts, which would reduce surface water $\mathrm{P}$ pollution. In general, $\mathrm{N}$ application rates have increased by approximately $10 \%$ in the last 45 years. Even though more $\mathrm{N}$ fertilizer has been used, offsets due to increased yields, better timing of fertilizer additions and better application location within the soil profile (closer to the roots) have been observed. Conversely, $\mathrm{P}$ application rates have remained the same or slightly decreased in the last 45 years. In addition, implemented soil erosion control efforts have reduced the quantity of $\mathrm{P}$ moving off fields and into surface waters. Based on historical $\mathrm{N}$ and $\mathrm{P}$ application rates it is estimated that farms within the selected study area have reduced their $\mathrm{N}$ and $\mathrm{P}$ loads to surface waters by $15 \%$ and $28 \%$, respectively. Keywords: historical use, nitrogen fertilizer applications, nutrient loads in surface waters, phosphorus fertilizer applications
\end{abstract}

\section{INTRODUCTION}

Over 15,000,000 ha of cropland are found within the Columbia-Snake River Watershed of the Pacific Northwest. Approximately 5,000,000 ha of land are irrigated, where the other $10,000,000$ ha are used in producing rain-fed crops. Within the rain-fed region there is some very productive land. One of these productive rain-fed regions is known locally as the Palouse. The Palouse is famous for consistently producing the highest rain-fed winter wheat yields in the world. However, to produce these consistently high yields large quantities of nitrogen and phosphorus fertilizers are applied to agricultural fields [1, 2]. A significant portion of the applied $\mathrm{N}$ and $\mathrm{P}$ leak into the surface waters of the region. Consequently, from historical, environmental, economic and practical standpoints it is important to know the application rates, application timing and placement of these fertilizers and tillage management practices on the farm to understand and prevent losses of these nutrients into the larger watershed.

\section{BACKGROUND}

Nitrogen is the major nutrient applied in winter wheat cropping systems in rain-fed areas of the Pacific Northwest [3-5]. Traditionally, most of the nitrogen has been applied in the fall prior to or at seeding. Most of the region's annual precipitation occurs between November and May, resulting in fertilizer $\mathrm{N}$ being in the soil when conditions are highly favourable for losses caused by leaching and denitrification. This timing of application technique 
results in relatively low nitrogen use efficiency (NUE) by the winter wheat crop. In drier areas ( $<475 \mathrm{~mm}$ annual precipitation), NUE usually ranges between $50 \%$ and $65 \%$. However, in the wetter areas ( $>475 \mathrm{~mm}$ annual precipitation) NUE is much lower and often ranges between $30 \%$ and 50\% [6]. The nitrogen loss is a result of leaching; however, it eventually moves laterally in the soil and is ultimately a surface loss to local rivers.

Water quality problems associated with $\mathrm{P}$ are generally confined to surface waters $[1,2,7]$. Many human activities contribute $\mathrm{P}$ to surface waters. Agricultural land enriched with $\mathrm{P}$ by fertilization can contribute substantial amounts of $P$ to surface waters as a result of runoff and/or erosional processes. Activities associated with modern agriculture often significantly increase soil erosion, water runoff and transport of sediment into surface waters. Surface water pollution from $\mathrm{P}$ is controllable by reducing soil erosion and thus keeping the soil out of creeks, streams, rivers and lakes. Specific management practices that will reduce P leakage into surface waters include (1) soil erosion control; (2) using P fertilizer application rates based on research and soil sampling; (3) correctly placing the P fertilizer near the seed and away from the soil surface; and (4) using conservation tillage practices including reduced tillage, minimum tillage, no-till and/or direct seeding.

The purpose of this article is to document changes in the use of nitrogen and phosphorus in agricultural settings in eastern Washington, northern Idaho and northeastern Oregon since 1971. To do this four mail-based grower surveys were conducted in 1981, 1996, 2011 and 2016. We documented changing $\mathrm{N}$ and $\mathrm{P}$ fertilizer use and their methods of placement within soils. In addition, the surveys documented erosion control efforts that reduce surface water $\mathrm{P}$ pollution. This report is a summary of our findings.

\section{METHODOLOGY}

Survey instruments containing between 28 and 33 questions were developed to access nutrient and soil management practices used by farmers in the $350-650 \mathrm{~mm}$ precipitation zone in the rain-fed farming area producing winter wheat in the Idaho, Oregon and Washington portions of the Inland Pacific Northwest [8-10]. The actual surveys were conducted in 1981, 1996, 2011 and 2016. All surveys contained the following six questions which were evaluated in this article:

Compared to 10 years ago, how has nitrogen fertilizer use on your farm changed?

Answer choices: use significantly more $N$, use slightly more $N$, no change, use slightly less $N$, use significantly less $N$

Compared to 10 years ago, how has phosphorus fertilizer use on your farm changed?

Answer choices: use significantly more $P$, use slightly more $P$, no change, use slightly less $P$, use significantly less $P$

What is your typical application rate of nitrogen to winter wheat (in $\mathrm{kg} / \mathrm{ha}$ )? Answer choices: $<50,50$ to 100,100 to 125,125 to $150,>150$

What is your typical application rate of phosphorus to winter wheat (in $\mathrm{kg} / \mathrm{ha}$ )? Answer choices: $<15,15$ to 30,30 to $60,>60$

What is your typical application method for nitrogen on winter wheat?

Answer choices: all pre-plant injected, all pre-plant, all applied at planting, all applied after planting, combination of pre-plant or at planting and a later application

What is the primary tillage method you use in winter wheat production?

Answer choices: conservation tillage, reduced/minimum tillage, no till/direct seeding 
The survey target audience was a representative sample of 2,500 farms in the area studied. In addition to the questions above demographic information including annual precipitation, number of years of farming experience, formal education level of the farm operator and size of farm were collected from survey respondents.

In each survey year, a target of 600 completed questionnaires was chosen as the survey goal to result in a sampling error of 4-7\% [11]. The survey process was designed to receive a completed survey return rate of more than $40 \%$. Addresses were obtained from county extension offices and USDA-NRCS field office mailing lists and four mailings were planned to achieve the $40 \%$ return rate $[12,13]$. The mailing strategy used was identical in all surveys that had been conducted in the region since 1970 [8-10].

It only took four mailings to achieve the target return rate of 40\% in 1981, 1996, 2011 and 2016. The first mailing included the water issues survey form, a business reply envelope and a cover letter that (1) identified the survey's authors; (2) explained the purpose of the survey; (3) assured the respondent of anonymity; and (4) asked the respondents to fill out and return the survey via the business reply envelope. The second mailing (4 weeks later) consisted of a postcard that stressed the importance of the survey and remind the respondent to fill out and return the survey sent out in the first mailing. Five weeks later the third mailing was sent to residents who did not respond to the first or second mailing. This mailing included a reminder letter, another copy of the water issues survey and a business reply envelope. The fourth mailing consisted of a reminder postcard 6 weeks after the third mailing.

Survey answers were coded and entered into Microsoft Excel. Missing data were excluded from the analysis. The data were analysed at two levels using SAS [13]. The first level of analysis generated frequencies, while the second level evaluated the impacts of demographic factors. Significance $(P<0.05)$ to demographic factors was tested using a chi-square distribution [11-13]. Since similar response rates were observed in all four survey years, data analysis procedures were identical for each sampling.

\section{RESULTS AND DISCUSSION}

The survey methodology used in the study was not designed to be unique, but rather to be used as a tool to ascertain useful information. The survey methodology was designed to access management practices used by farmers on their land in eastern Washington, northeastern Oregon and northern Idaho over a 45-year period.

All four survey years achieved a survey return rate goals of more than $50 \%[11,12]$. The 1981, 1996, 2011 and 2016 survey response rates were 56.4\%, 51.3\%, 54.2\% and 50.7\%, respectively. Consequently, when coupled with the low sampling error of the survey, respondents can be equated to residents in the following discussion. The average survey respondent had farmed for 34 years and was 61 years old. Based on survey demographics the surveyed growers were representative of the actual demographics of farmers living in the region.

\subsection{Nitrogen management of farms in the region}

Farmers in this region have been applying constant rates of $\mathrm{N}$ to their winter wheat crops for the last 45 years (Table 1). Over one-third of the farmers indicated that they have not changed their $\mathrm{N}$ application rates, while between $34.0 \%$ and $46.5 \%$ claimed to have slightly increased $\mathrm{N}$ application rates, depending on the survey year. Conversely, few farmers have significantly increased or significantly decreased their $\mathrm{N}$ application rates on winter wheat over time. 
Table 1: Nitrogen fertilizer rate application trends over the previous 10-year periods for winter wheat based on results from the 1981, 1996, 2011 and 2016 grower nutrient surveys.

\begin{tabular}{lrrrr}
\hline Nitrogen application rate trend & \multicolumn{4}{c}{ Year $(\%)$} \\
\cline { 2 - 5 } & 1981 & 1996 & 2011 & 2016 \\
\hline Significantly higher & 15.4 & 10.2 & 8.0 & 6.4 \\
Slightly higher & 46.5 & 40.4 & 38.1 & 34.0 \\
No change & 33.2 & 36.4 & 38.1 & 34.0 \\
Slightly lower & 4.0 & 8.7 & 12.3 & 10.3 \\
Significantly lower & 0.9 & 4.3 & 3.5 & 4.2 \\
\hline
\end{tabular}

Table 2: Nitrogen fertilizer rate application trends over the last 45 years (comparing 1971 with 2016) for winter wheat based on historical annual precipitation data and grower surveys.

\begin{tabular}{ll}
\hline Annual precipitation zone $(\mathrm{mm})$ & Nitrogen application trends \\
\hline$<425$ & No change \\
$425-475$ & No change \\
$475-525$ & Slightly higher \\
$525-575$ & No change \\
$>575$ & Slightly lower \\
\hline
\end{tabular}

When the four survey years are pooled and $\mathrm{N}$ application rates are separated by the amount of annual precipitation a farm received important trends can be observed (Table 2). First, $\mathrm{N}$ application rates on winter wheat have not changed in areas receiving less than $450 \mathrm{~mm}$ of annual precipitation. This is because water is the most limiting factor in wheat yields in these two precipitation zones. Consequently, further $\mathrm{N}$ additions would not increase wheat yields. Second, farmers in the $475-525 \mathrm{~mm}$ precipitation zone have slightly increased applications of $\mathrm{N}$ to winter wheat crops over the last 45 years. Here improved management practices may have resulted in both increased $\mathrm{N}$ application rates and higher winter wheat yield (Table 2).

Third, $\mathrm{N}$ applications have remained flat in the $525-575 \mathrm{~mm}$ precipitation area (Table 2). Again, better management practices may have allowed wheat yields to actually increase without a corresponding increase in $\mathrm{N}$ fertilizer use. Fourth, $\mathrm{N}$ application rates have actually decreased in the wettest wheat growing precipitation zone. This observation will be explained later in the article when $\mathrm{N}$ management is further explained.

Nitrogen fertilizer application rates on winter wheat over the last 45 years have ranged from 0 to $180 \mathrm{~kg} / \mathrm{ha}$. The average $\mathrm{N}$ application rate based on the four surveys was $95 \mathrm{~kg} \mathrm{~N} / \mathrm{ha}$. A majority of farmers have typically applied between 50 and $100 \mathrm{~kg} \mathrm{~N} / \mathrm{ha}$ per winter wheat crop (Table 3). By 2016, 30\% of growers were applying more than $100 \mathrm{~kg}$ N/ha per wheat crop. When evaluated more closely, the consistency of $\mathrm{N}$ application rates over time is 
Table 3: Nitrogen fertilizer rate applications for winter wheat based on results from the 1981, 1996, 2011 and 2016 grower nutrient surveys.

\begin{tabular}{lcccr}
\hline Nitrogen application rate $(\mathrm{kg} / \mathrm{ha})$ & \multicolumn{4}{c}{ Year $(\%)$} \\
\cline { 2 - 5 } & 1981 & 1996 & 2011 & 2016 \\
\hline$<50$ & 15.2 & 16.8 & 13.4 & 12.6 \\
$50-100$ & 60.2 & 60.8 & 55.8 & 57.4 \\
$100-125$ & 16.0 & 13.0 & 14.3 & 15.2 \\
$125-150$ & 4.1 & 4.2 & 14.2 & 10.7 \\
$>150$ & 4.5 & 5.2 & 2.3 & 4.1 \\
\hline
\end{tabular}

apparent. There were no statistical differences in $\mathrm{N}$ application rates that could be tied to time (survey year) over the 45-year study period.

\subsection{Phosphorus management of farms in the region}

Historical $\mathrm{P}$ application rate trends on winter wheat are shown in Table 4. A majority of survey respondents have not changed the quantity of $\mathrm{P}$ fertilizers applied to wheat over time. Back in 1981 over $45 \%$ of the farmers had increased their $\mathrm{P}$ application rates from the previous 10-year period (1971-1981).

Phosphorus application rate trends over the last 45 years are shown in Table 5. The trends shown indicate that annual precipitation zone had an effect on $\mathrm{P}$ fertilization in this rain-fed region. First, $\mathrm{P}$ application rates have not changed in areas receiving less than $475 \mathrm{~mm}$ of annual precipitation. This result mirrors the $\mathrm{N}$ fertilization trends in this rainfall regime. Again, $\mathrm{P}$ rates have probably remained the same in this zone because lack of water has been the major factor limiting winter wheat yield. Thus, changes in P use would only have a minimal impact on winter wheat yield potential.

Phosphorus fertilizer application rates were slightly higher in 2016 compared to 1981 in the 475-575 annual precipitation zones (Table 5). Here agronomic practices initiated in these rainfall zones in the last 25-35 years have increased wheat yield potentials. This in turn has resulted in a higher rate of $\mathrm{P}$ fertilizer applications. No change in fertilizer $\mathrm{P}$ application rates was observed in the zone where annual precipitation exceeded $575 \mathrm{~mm}$.

Table 4: Phosphorus fertilizer rate application trends over the previous 10-year periods for winter wheat based on results from the 1981, 1996, 2011 and 2016 grower nutrient surveys.

\begin{tabular}{lrrrr}
\hline \multirow{2}{*}{ Phosphorus application rate trend } & \multicolumn{4}{c}{ Year (\%) } \\
\cline { 2 - 5 } & 1981 & 1996 & 2011 & 2016 \\
\hline Significantly higher & 30.6 & 18.4 & 8.0 & 4.2 \\
Slightly higher & 15.3 & 18.0 & 28.0 & 20.4 \\
No change & 58.4 & 47.2 & 51.6 & 56.4 \\
Slightly lower & 4.1 & 13.4 & 9.0 & 14.5 \\
Significantly lower & 1.6 & 3.0 & 3.4 & 4.5 \\
\hline
\end{tabular}


Table 5: Phosphorus fertilizer rate application trends over the last 45 years (comparing 1971 with 2016) for winter wheat based on historical annual precipitation data and grower surveys.

\begin{tabular}{ll}
\hline Annual precipitation zone $(\mathrm{mm})$ & Phosphorus application trends \\
\hline$<425$ & No change \\
$425-475$ & No change \\
$475-525$ & Slightly higher \\
$525-575$ & Slightly higher \\
$>575$ & No change \\
\hline
\end{tabular}

Table 6: Phosphorus fertilizer rate applications for winter wheat based on results from the 1981, 1996, 2011 and 2016 grower nutrient surveys.

\begin{tabular}{lrrrr}
\hline Phosphorus application rate $(\mathrm{kg} / \mathrm{ha})$ & \multicolumn{4}{c}{ Year $(\%)$} \\
\cline { 2 - 5 } & 1981 & 1996 & 2011 & 2016 \\
\hline$<15$ & 46.1 & 49.5 & 40.2 & 37.5 \\
$15-30$ & 45.1 & 43.4 & 49.5 & 53.4 \\
$30-60$ & 8.2 & 6.9 & 10.1 & 9.7 \\
$>60$ & 0.0 & 0.2 & 0.2 & 0.4 \\
\hline
\end{tabular}

Phosphorus fertilizer application rates over the last 45 years have ranged from 0 to $70 \mathrm{~kg} / \mathrm{ha}$. The average $\mathrm{P}$ application rate on winter wheat in this region based on grower surveys was $22 \mathrm{~kg} / \mathrm{ha}$. A majority of farmers have typically applied between 15 and $30 \mathrm{~kg} \mathrm{P} /$ ha per wheat crop (Table 6). In 2016, $11.4 \%$ of growers were applying more than $30 \mathrm{~kg} \mathrm{P} / \mathrm{ha}$ per wheat crop. Conversely, $37.5 \%$ of growers were applying less than $15 \mathrm{~kg} \mathrm{P} / \mathrm{ha}$. As with the $\mathrm{N}$ application data, the $\mathrm{P}$ data show the consistency of $\mathrm{P}$ application rates over the previous 45 years.

\subsection{Tillage management of farms in the region}

The primary tillage method used on winter wheat by farmers in the region is shown in Table 7. The primary type of tillage has changed over the last 45 years. In 1981, over $70 \%$ of farmers were using the traditional conventional tillage practice. In 2016, only $20 \%$ of the growers were still using conventional as their primary tillage practice. The use of reduced/minimum tillage increased from $28.3 \%$ of growers in 1981 to almost $50 \%$ by 2016 (Table 7). No-till/ direct seeding was used by less than $2 \%$ of farmers in 1981, but had grown to be used by almost one-third of farmers in 2011 and 2016.

The demographic factors of grower experience, grower education level and survey year also significantly impacted the use of reduced/minimum tillage (Table 8 ). When survey years were pooled, growers with less than 10 years of farming experience were more likely to use reduced/minimum tillage than growers that had been farming for more than 25 years $(68.3 \%$ vs $49.4 \%$ ). It appears that the farmers with less experience were more likely to use reduced tillage practices to reduce soil erosion. 
Table 7: Primary tillage method identified by growers in 1981, 1996, 2011 and 2016 surveys.

\begin{tabular}{lrccc}
\hline Tillage method & \multicolumn{4}{c}{ Year (\%) } \\
\cline { 2 - 5 } & 1981 & 1996 & 2011 & 2016 \\
\hline Conventional tillage & 70.1 & 40.4 & 25.6 & 20.4 \\
Reduced/minimum tillage & 28.3 & 44.1 & 43.0 & 49.4 \\
No-till/direct seeding & 1.6 & 15.5 & 31.4 & 30.2 \\
\hline
\end{tabular}

Table 8: The influence of demographic factors of grower experience, education level and survey year on the use of reduced tillage (reduced + minimum + no-till + direct seeding) in winter wheat cropping systems based on 1981, 1996, 2011 and 2016 grower surveys.

\begin{tabular}{llcc}
\hline Demographic factor & Parameter & Using reduced tillage (\%) & Significance \\
\hline Grower experience & <10 years & 68.3 & $* *$ \\
& 10-25 years & 60.4 & \\
2 25 years & 49.4 & $* *$ \\
Survey year & High school & 52.9 & \\
& Some college & 62.4 & $* * *$ \\
& College graduate & 73.8 & \\
& 1981 & 29.9 & \\
\hline
\end{tabular}

Formal education level of farmers also impacted the type of tillage used on farms (Table 8). Farmers that were college graduates were more likely to use reduced/minimum tillage practices than farmers with fewer years of formal schooling. Conversely, farmers with only a high school diploma were less likely to use reduced/minimum tillage. In general, the greater the level of formal education the more likely the grower used reduced/minimum tillage.

Survey year also had a significant impact on the use of reduced/minimum tillage by farmers (Table 8). Back in 1981, less than $30 \%$ of growers used reduced/minimum tillage; however, by 2016 almost $80 \%$ employed this practice.

Tillage management is a very important practice that can be used to reduce $\mathrm{N}$ and $\mathrm{P}$ leakage from fields into surface water bodies in the region. For instance, soil erosion rates of 15-35, $3-12$ and $<3 \mathrm{mt} / \mathrm{ha}$ are common under wheat management conditions of conventional tillage, minimum/reduced tillage and no-till/direct seeding, respectively.

Since most $\mathrm{P}$ loss from soils is through surface erosion, changing tillage practices to minimum or no-till will greatly reduce $\mathrm{P}$ emissions from farmland to surface waters. Even though $\mathrm{P}$ fertilizer application rates have not been reduced in the last 45 years, the shift to tillage practices that greatly reduce soil erosion substantially reduces the P load from agriculture.

The use of reduced tillage practices to prevent soil erosion probably does not have a big impact on $\mathrm{N}$ leakage into the surface waters of the region. This is because nitrogen fertilizer 
is mobile in the soil and likely leaches into the soil below the active erosive surface of the soil profile. Consequently, erosion control has little impact on reducing $\mathrm{N}$ in surface waters.

\subsection{Placement and timing of nitrogen applications}

The primary application method of $\mathrm{N}$ fertilizers on winter wheat is shown in Table 9. Based on collected survey data farmers have employed six basic methods of $\mathrm{N}$ application to winter wheat. Back in 1981, 100\% pre-plant injected (34.6\%), 100\% applied at planting (24.0\%) and a combination of pre-plant or at planting with a partial spring top-dress application (20.4\%) were the three most common $\mathrm{N}$ application methods. In 2016, the three methods listed earlier were still the most common methods used to apply $\mathrm{N}$; however, their order of use had changed (Table 9). In 2016, the combination of all pre-plants or at planting with a spring top-dress application was the most common method (41.4\%). The growers that used this method indicated that their total $\mathrm{N}$ application rate did not change, but rather, they were applying a higher portion of their total $\mathrm{N}$ in the spring. Split applications such as these have been shown to improve NUE in crops, resulting in less leakage into the environment.

This observation is made more credible when combined with the data shown in Table 10. Here the percentage of farmers applying $25-50 \%$ of their total $\mathrm{N}$ to winter wheat in the spring increased from $12.4 \%$ in 1981 to $29.3 \%$ in 2016 . There could be many reasons for the increased use of split applications; however, there are two obvious explanations. First, split applications improve NUE which is important for the producers' economic bottom line.

Table 9: Primary application method of nitrogen fertilizer on winter wheat identified by farmers in 1981, 1996, 2011 and 2016 surveys.

\begin{tabular}{lrrrr}
\hline Nitrogen application method & \multicolumn{4}{c}{ Year (\%) } \\
\cline { 2 - 5 } & 1981 & 1996 & 2011 & 2016 \\
\hline All pre-plant injected & 34.6 & 32.1 & 30.7 & 28.4 \\
All pre-plant & 18.6 & 18.2 & 14.8 & 8.2 \\
All applied at planting & 24.0 & 19.6 & 22.3 & 20.3 \\
All applied after planting & 2.4 & 3.0 & 3.1 & 1.7 \\
Combo-pre-plant/at plant + spring & 20.4 & 27.1 & 36.0 & 41.4 \\
\hline
\end{tabular}

Table 10: The percentage of fields receiving spring top-dress applications of nitrogen based on 1981, 1996, 2011 and 2016 grower surveys.

\begin{tabular}{lrrrr}
\hline Percent of the nitrogen & \multicolumn{4}{c}{ Year $(\%)$} \\
\cline { 2 - 5 } applied in spring & 1981 & 1996 & 2011 & 2016 \\
\hline$<25$ & 86.2 & 80.0 & 62.3 & 59.5 \\
$25-50$ & 12.4 & 16.6 & 24.2 & 29.3 \\
$50-75$ & 1.0 & 2.7 & 6.9 & 6.0 \\
$>75$ & 0.4 & 0.7 & 6.6 & 5.2 \\
\hline
\end{tabular}


Table 11: The percent of nitrogen applied to winter wheat the spring after planting based on annual precipitation zone.

\begin{tabular}{lrrrr}
\hline Annual precipitation $(\mathrm{mm})$ & \multicolumn{4}{c}{ Year $(\%)$} \\
\cline { 2 - 5 } & 1981 & 1996 & 2011 & 2016 \\
\hline$>425$ & 5.0 & 6.2 & 4.3 & 2.9 \\
$425-475$ & 10.7 & 10.6 & 12.7 & 13.2 \\
$475-525$ & 12.3 & 12.4 & 17.2 & 18.9 \\
$525-575$ & 19.6 & 24.5 & 29.4 & 32.8 \\
$>575$ & 23.4 & 25.9 & 35.2 & 34.9 \\
\hline
\end{tabular}

Second, $\mathrm{N}$ fertilizer costs have escalated in the last 20 years to the point it is applied when needed instead of just as insurance to produce the desired yield. Both explanations tie into simple economics. The reduced $\mathrm{N}$ load in local surface waters is an important side benefit.

Split applications (part in the fall, part in the spring) were most commonly adapted in the wetter precipitation areas, where NUE values are the lowest. Split application N management increased between 1981 and 2016 in the 475-525, 525-575 and >575 annual precipitation zones (Table 11). In 2016, over $30 \%$ of the $\mathrm{N}$ applied by growers in the wettest region was being applied in the spring.

\section{CONCLUSIONS AND RECOMMENDATIONS}

$\mathrm{N}, \mathrm{P}$ and tillage data collected over the last 45 years in the region suggest that $\mathrm{N}$ and $\mathrm{P}$ leakage from farmland into the region's rivers has been substantially reduced. Specific findings include:

- Nitrogen fertilizer use has increased by about $10 \%$ in the last 45 years. Application rates over the last 45 years have ranged from 0 to $180 \mathrm{~kg} / \mathrm{ha}$, with the average application rate of $95 \mathrm{~kg} \mathrm{~N} / \mathrm{ha}$. A majority of farmers have typically applied between 50 and $100 \mathrm{~kg} \mathrm{~N} / \mathrm{ha}$ per winter wheat crop.

- Phosphorus fertilizer use has remained constant over the last 45 years. Application rates over the last 45 years have ranged from 0 to $70 \mathrm{~kg} / \mathrm{ha}$, with an average application rate of $22 \mathrm{~kg} / \mathrm{ha}$. A majority of farmers have typically applied between 15 and $30 \mathrm{~kg}$ P/ha per wheat crop.

- The primary type of tillage has changed over the last 45 years. In 1981, over $70 \%$ of farmers were using the traditional conventional tillage practice. The use of reduced/minimum tillage increased from $28.3 \%$ of growers in 1981 to almost $50 \%$ by 2016 .

- Since most P loss from soils is through surface erosion, changing tillage practices to minimum or no-till greatly reduced leakage into surface waters.

- Split applications of $\mathrm{N}$ fertilizers have been shown to improve NUE, resulting in less $\mathrm{N}$ leakage into surface waters.

\section{REFERENCES}

[1] Mahler, R.L., Northern Idaho Fertilizer Guide: Winter Wheat, University of Idaho College of Agriculture, Moscow, ID, Current Information Series No. 453 (revision), 2007.

[2] McDole, R.E., \& Mahler, R.L., Northern Idaho Fertilizer Guide: Winter Wheat, University of Idaho College of Agriculture, Moscow, ID, Current Information Series No. 453, 1985. 
[3] Smith, R.A., Alexander, R.B., \& Wolman, M.G., Water quality trends in the nation's rivers, Science, 235, pp. 1607-1613, 1987. DOI: 10.1126/science.235.4796.1607.

[4] Alexamder, R.B., Smith, R.A., Schwarz, G.E., Boyer, E.W., Nolan, J.V., \& Brakebill, J.W., Differences in phosphorus and nitrogen delivery to the Gulf of Mexico from the Mississippi River Basin. Environmental Science and Technology, 42(3), pp. 822-830, 2008. DOI: 10:1021/es0716103.

[5] Huang, W., Heifner, R.G., Taylor, H., \& Uri, N.D., Timing nitrogen fertilizer application to reduce nitrogen losses to the environment. Water Resources Management, 14, pp. 35-58, 2000. DOI: 10.1023/A:1008137011813.

[6] Lutcher, L.K., \& Mahler, R.L., Sources and timing of spring top-dress nitrogen on winter wheat in Idaho. Agronomy Journal, 80, pp. 648-654, 1988. DOI: 10.2134/agronj19 88.00021962008000040020x.

[7] Sharpley, A.N., Chapra, S.C., Wedepohl, R., Sims, J.T., Daniel, T.C., \& Reddy, K.R., Managing agricultural phosphorus for protection of surface waters: Issues and options. Journal of Environmental Quality, 23(3), 437-451, 1993. DOI: 10.2134/ jeq1994.00472425002300030006x.

[8] Mahler, R.L., Simmons, R., Sorensen, F. \& Miner, J.R., Priority water issues in the Pacific Northwest. Journal of Extension, 42(5), Article 5RIB3, available at http://www. joe.org/joe/2004october/rb3.php, 2004 (accessed 5 June 2014).

[9] Mahler, R.L., Gamroth, M., Pearson, P., Sorenson, F., Barber, M.E. \& Simmons, R., Information sources, learning opportunities and priority water issues in the Pacific Northwest. Journal of Extension, 48(2), Article 2RIB2, available at http://www.joe.org/ joe/2010april/rb2.php, 2010 (accessed 5 June 2014).

[10] Mahler, R.L., Simmons, R. \& Sorensen, F., Drinking water issues in the Pacific Northwest. Journal of Extension, 43(6), 6RIB6, available at http://www.joe.org/ joe/2005december/rb6.php, 2005 (accessed 5 June 2014).

[11] Salent, P. \& Dillman, D., How to Conduct Your Own Survey, John Wiley and Sons, Inc.: New York, NY, 1994.

[12] Dillman, D., Mail and Internet Surveys: The Tailored Design Method. John Wiley and Sons, Inc.: New York, NY, 2000.

[13] SAS Institute Inc., SAS Online Document 9.1.3., SAS Institute Inc.: Cary, NC, 2004. 